\title{
Magnetite Nanoparticles Biomineralization in the Presence of the Magnetosome Membrane Protein MamC: Effect of Protein Aggregation and Protein Structure on Magnetite Formation
}

Rafael Lopez-Moreno, ${ }^{\dagger}$ Antonia Fernández-Vivas, $^{\dagger}$ Carmen Valverde-Tercedor, $^{\dagger}$ Ana I. Azuaga Fortes, ${ }^{*}$ Salvador Casares Atienza, ${ }^{\ddagger}$ Alejandro B. Rodriguez-Navarro, ${ }^{\S}$ Raz Zarivach, ${ }^{\|}$ and Concepcion Jimenez-Lopez ${ }^{*} \dagger$

\footnotetext{
${ }^{\dagger}$ Department of Microbiology, ${ }^{\ddagger}$ Department of Physical Chemistry, and ${ }^{\S}$ Department of Mineralogy and Petrology, University of Granada, Campus de Fuentenueva s/n, 18071 Granada, Spain

"Department of Life Sciences, the National Institute for Biotechnology in the Negev and the Ilse Katz Institute for Nanoscale Science, Ben-Gurion University of the Negev, Beer Sheva, Israel
}

Supporting Information

ABSTRACT: MamC from Magnetococcus marinus MC-1 has been shown to control the size of magnetite crystals in in vitro experiments, thereby demonstrating its potential as a candidate protein for the production of magnetite nanoparticles possibly useful in medical and other applications. However, the importance of the structure and aggregation state of the protein on the resulting biomimetic nanoparticles has not yet been assessed. One method normally used to prevent the aggregation of integral membrane proteins is the introduction of detergents during protein purification. In this study, results from protein aggregation following the addition of Triton-X100, DDM, and LDAO are presented. Magnetite particles formed in the presence of MamC purified using these three detergents were compared. Our results show that detergents alter the structure of the folded recombinant protein, thus preventing the ability of MamC to control the size of magnetite crystals formed chemically in vitro. Furthermore, we show that the introduction of detergents only at the dialysis process during the protein purification prevents its aggregation and allows for correct, functional folding of MamC. These results also indicate that the population of the active protein particles present at a certain oligomeric state needs to be considered, rather than only the oligomeric state, in order to interpret the ability of magnetosome recombinant proteins to control the size and/or morphology of magnetite crystals formed chemically in vitro.

\section{INTRODUCTION}

Magnetotactic bacteria (MTB) are a diverse group of microorganisms that have in common the ability to passively align and to actively swim along the Earth's magnetic field lines. ${ }^{1}$ This is because MTB biomineralize single magnetic domain magnetite $\left(\mathrm{Fe}_{3} \mathrm{O}_{4}\right)$ or greigite $\left(\mathrm{Fe}_{3} \mathrm{~S}_{4}\right)$ crystals through a controlled biomineralization process, ${ }^{2,3}$ which results in magnetic nanocrystals with specific characteristics, such as a nonisometric morphology, high chemical purity, size distribution within the single magnetic domain range, and a nearly perfect crystal structure. ${ }^{4}$ Magnetosome nanocrystals are surrounded by a lipid bilayer forming the magnetosome organelle. ${ }^{2}$ Being also biocompatible, ${ }^{5,6}$ magnetosomes could be used in many biomedical applications as in cell separation, ${ }^{7}$ magnetic resonance imaging, ${ }^{8}$ DNA extraction, ${ }^{9}$ detection of SNPs, ${ }^{7,10,11}$ hyperthermia cancer treatments, ${ }^{12}$ and as drug carriers. $^{13}$

However, scaling up magnetosome production to industrial levels is complicated since MTB are difficult to culture. Kolinko et al. $^{14}$ were successful expressing magnetosome-related genes in a nonmagnetotactic bacterium, Rhodospirillum rubrum, to the point of obtaining "heterologous" magnetosomes in a bacteria that is easier to grow than MTB. Nevertheless, the viability of the industrial production of those heterologous "magnetosomes" has not been yet studied and those nanocrystals have not been extensively characterized to determine whether or not they represent an alternative to magnetosomes produced by MTB. As a second alternative, biomimetics is claimed to produce in vitro magnetosome-like magnetite nanoparticles, without the need of scaling bacterial cultures, through the formation of magnetite mediated by recombinant magnetosome proteins. ${ }^{15-23}$

Magnetosome biomineralization process is assumed to be controlled by certain magnetosome-associated proteins. ${ }^{21,23}$ Among these, a set of them seem to regulate the size and morphology of the magnetite crystal, which are decisive

Received: November 12, 2016

Revised: February 6, 2017

Published: February 13, 2017 
parameters to determine the magnetic properties of these nanoparticles. These proteins are of great interest for the synthesis of biomimetic particles. Although the most studied protein is Mms6 from Magnetospirillum gryphiswaldense, ${ }^{15-19}$ Valverde-Tercedor et $\mathrm{al}^{20}$ recently proposed MamC from Magnetococcus marinus $\mathrm{MC}-1$ as a new candidate to in vitro obtain biomimetic magnetites larger in size than those produced by using Mms6. Magnetites produced in the presence of MamC present magnetic properties compatible with having a well crystallized structure. ${ }^{20}$ On one hand, MamC is able to bind iron, thus creating high supersaturation areas, with respect to magnetite, in those domains rich in acidic amino acids. ${ }^{20}$ Also, Nudelman et al. ${ }^{24}$ suggested a template mechanism for magnetite precipitation according to the coincident distance between the iron cations planes in several magnetite faces and between two acidic amino acids in the MamC loop (Glu 66 and Asp 70). ${ }^{24}$

To date, the only purification protocol for a full-length recombinant MamC results in the formation of protein aggregates, originally observed Kaysap et al. ${ }^{25}$ These protein aggregates may pose problems in magnetite biomineralization experiments for several reasons. On one hand, acidic amino acids may be enclosed within the aggregate, thus losing the potential to interact with the aqueous iron cations or, conversely, even though they may be exposed on the surface of the aggregate, such an aggregation may prevent the protein to adopt the adequate folding necessary to result in an extended surface, as proposed by Nudelman et al. $^{24}$ to template the nucleation. For this reason, it is important to modify the protein purification protocol to obtain MamC at different oligomerization states (i.e., monomers, dimers, or trimers) in order to disentangle the actual effect of the protein particles on magnetite precipitation and to optimize the production of MamC-derived magnetites.

\section{MATERIALS AND METHODS}

Expression and Purification of Recombinant-MamC. MamC was purified as a polyhistidine fusion protein following the protocol described by Valverde-Tercedor et al. ${ }^{20}$ For the expression of MamC, E. coli TOP10 transformed with $\mathrm{pTrcHis-TOPO}$ mamC was cultured in LB broth supplemented with $50 \mathrm{mg} / \mathrm{mL}$ of ampicillin (SigmaAldrich). The culture was incubated at $37^{\circ} \mathrm{C}$ with shaking at $200 \mathrm{rpm}$ until an optical density of 0.6 was reached (Biochrom, Libra S12). Recombinant-MamC expression was induced by adding IPTG (2 $\mathrm{mM})$ to the culture. The cell pellet recovered after induction was resuspended in guanidinium lysis buffer (guanidinium hydrochloride 6 $\mathrm{M}$, sodium phosphate $20 \mathrm{mM}, \mathrm{NaCl} 500 \mathrm{mM}, \mathrm{pH}$ 7.8). After disruption by ultrasonication, the cell lysate was centrifuged and the supernatant was loaded onto a HiTrap chelating HP column (GE Healthcare) equilibrated with denaturing binding buffer (urea $8 \mathrm{M}$, sodium phosphate $20 \mathrm{mM}, \mathrm{NaCl} 500 \mathrm{mM}, \mathrm{pH} 7.8$ ) to purify MamC protein by an IMAC chromatography. After loading, the column was washed with 15 volumes of binding buffer, followed by 10 volumes of denaturing washing buffer (urea $8 \mathrm{M}$, sodium phosphate $20 \mathrm{mM}, \mathrm{NaCl}$ $500 \mathrm{mM}, \mathrm{pH} 6.0)$. The protein was eluted with denaturing elution buffer (urea $8 \mathrm{M}$, sodium phosphate $20 \mathrm{mM}, \mathrm{NaCl} 500 \mathrm{mM}, \mathrm{pH} 4.0$ ). Fractions containing MamC protein were dialyzed against $1 \mathrm{~L}$ of buffer A (Tris $50 \mathrm{mM}, \mathrm{NaCl} 150 \mathrm{mM}$, urea $6 \mathrm{M}, \mathrm{pH} 8.5$ ) and diluted stepwise with buffer B (Tris $50 \mathrm{mM}, \mathrm{NaCl} 150 \mathrm{mM}, \mathrm{pH} 8.5$ ) every $4 \mathrm{~h}$. Finally, it was dialyzed against buffer B overnight.

Given the fact that this purification protocol resulted in protein aggregates, further modifications of this protocol were tested in order to minimize protein aggregation. Different detergents were tested as dispersing agents: triton X-100 (Prolabo), N,N-dimethyldodecylamine $N$-oxide (LDAO, Carbosynth), and dodecyl $\beta$-D-maltopyranoside (DDM, Carbosynth). Detergents (one per experiment) were introduced during the purification protocol at two different stages, giving rise to two different types of experiments: (1) detergent-MamC type (i.e., DDM-MamC, LDAO-MamC, and Triton-MamC); the relevant detergent was added to the cell lysate and to all the buffers thereafter at 1.3 critical micelle concentration (CMC); and (2) detergent-D-MamC type (D stands for dialysis; i.e. DDM-D-MamC, LDAO-D-MamC and Triton-D-MamC); the relevant detergent was added only during the dialysis process (10 CMC as initial concentration and 1.3 CMC final concentration). MamC was also purified in the absence of detergents, acting as control. This set of experiments is here referred to as MamC-control type. The purity of the isolated proteins was estimated by SDS-PAGE. Isolated proteins were stored at $4{ }^{\circ} \mathrm{C}$ until analysis.

Refolding state of MamC was analyzed by using circular dichroism (CD) and dynamic light scattering (DLS) was used to calculate percentage and sizes of protein aggregates. Samples were centrifuged for $30 \mathrm{~min}$ at $14000 \mathrm{rpm}$ before those analyses. $\mathrm{CD}$ analyses were carried out by using a spectrometer JASCO J-715 at $25{ }^{\circ} \mathrm{C}$ in far UV spectra $(215-250 \mathrm{~nm})$ with a $1 \mathrm{~nm}$ bandwidth and a scan rate of 100 $\mathrm{nm} / \mathrm{min}$. Five scans of each sample were accumulated for the analysis and the background spectrum (buffer B with or without detergent) was subtracted.

DLS analyses (DynaPro MS-X, Wyatt, Santa Barbara, CA, USA) were monitored at $25{ }^{\circ} \mathrm{C}$ by using a thermostated $30 \mu \mathrm{L}$ quartz cuvette. DLS data were acquired every $45 \mathrm{~s}$ until saturation of the signal. The laser power was adjusted to avoid early saturation. Dynamics $\mathrm{v} 6$ software was used in data collection and processing of the correlation function to finally obtain the particle size distributions.

Biomineralization Experiments. All reagents used in the biomineralization experiments were purchased from Sigma-Aldrich. The deoxygenated water used in these experiments was prepared by boiling nanopurified water for $1 \mathrm{~h}$ and then cooling in an ice bath while continuously sparging with ultrapure $\mathrm{N}_{2}$. After that, it was immediately placed inside an anaerobic chamber (Coy Laboratory Products, Grass Lake, MI) filled with $4 \% \mathrm{H}_{2}$ in $\mathrm{N}_{2}$, and used to prepare the stock solutions: $\mathrm{NaHCO}_{3} / \mathrm{Na}_{2} \mathrm{CO}_{3}(0.15 \mathrm{M} / 0.15 \mathrm{M})$, $\mathrm{FeCl}_{3}(1 \mathrm{M}), \mathrm{Fe}\left(\mathrm{ClO}_{4}\right)_{2}(0.5 \mathrm{M})$, and $\mathrm{NaOH}(5 \mathrm{M})$.

Magnetite precipitation experiments were carried out in the anaerobic chamber to avoid potential oxidation of the product. Inorganic magnetite was precipitated from solutions in free-drift experiments held at $25{ }^{\circ} \mathrm{C}$ and $1 \mathrm{~atm}$ total pressure, following the protocol described by Perez-Gonzalez et al. ${ }^{26}$ Magnetite synthesis was produced after mixing the stock solutions to a final concentration of $\mathrm{NaHCO}_{3} / \mathrm{Na}_{2} \mathrm{CO}_{3}(3.5 \mathrm{mM} / 3.5 \mathrm{mM}), \mathrm{FeCl}_{3}(5.56 \mathrm{mM})$, and $\mathrm{Fe}\left(\mathrm{ClO}_{4}\right)_{2}(2.78 \mathrm{mM}) . \mathrm{NaOH}$ was used to reach a $\mathrm{pH}$ value of 9 . Three type of inorganic control experiments (protein-free) were used, in which the final concentration of the solution detailed above was reached by adding, to the appropriate mixture of stock solutions, the following: (1) water (here referred to as wt-control), (2) buffer (here referred to as b-control), and (3) buffer + detergent (here referred to as bdet-control). In these last cases, the buffer (and detergent in bdetcontrol experiments) was added to a final concentration equal to that in the protein-bearing experiments. Protein-bearing magnetite precipitation experiments were carried out by adding to the mixture a concentration of $10 \mu \mathrm{g} / \mathrm{mL}$ of the purified MamC, with or without the corresponding detergents.

Characterization of the Solids. Solids in liquids were magnetically concentrated and the clear supernatants were discarded. The magnet was removed and the solids were resuspended in $\mathrm{O}_{2}$-free deoxygenated water, concentrated again with the magnet and the clear supernatant discarded. Solids from each experiment were washed three times this way. After solids collection, samples were immediately freeze-dried (FLEXI-DRY- $\mu \mathrm{P}$ ) and stored inside the anaerobic chamber until analysis.

Powder X-ray diffraction (XRD) analysis was carried out with an Xpert Pro X-ray diffractometer (PANalytical; The Netherlands) using $\mathrm{Cu} \mathrm{K} \alpha$ radiation, with the scan range set from $20^{\circ}$ to $60^{\circ}$ in $2 \theta\left(0.01^{\circ} \%\right.$ step; $3 \mathrm{~s}$ per step). Identification of the precipitates was performed using the XPowder software. ${ }^{27}$ 

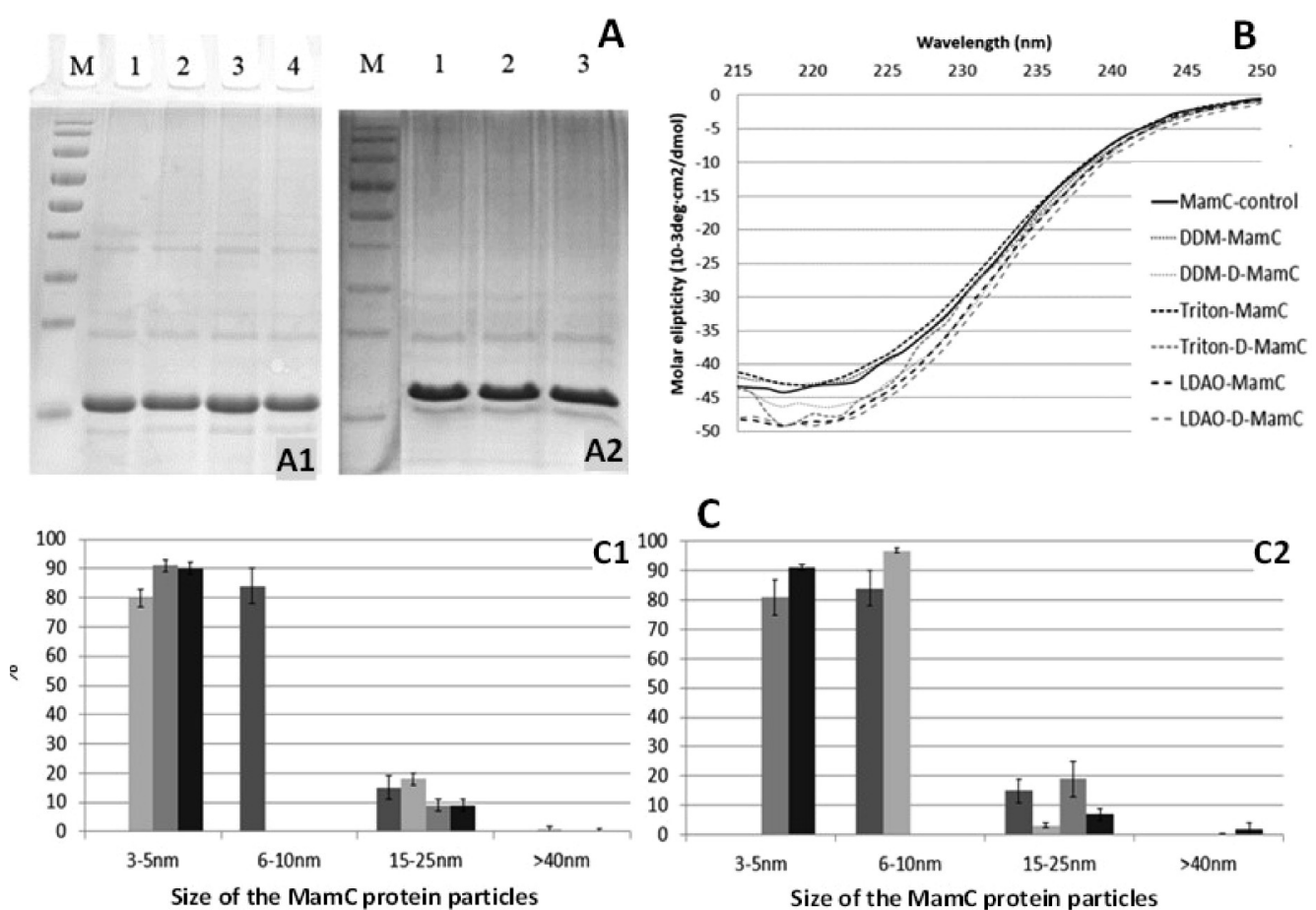

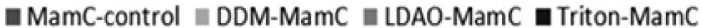

Figure 1. (A) One-dimensional SDS-PAGE gel stained with Coomassie Brilliant Blue R250 of purified MamC (A1) without detergents (lane 1), and in detergent-D-MamC experiment types (lane 2, LDAO; lane 3 DDM; and lane 4, Triton X-100) and in (A2) detergent-MamC experiment types (lane 1, LDAO; lane 2, DDM; and lane 3, Triton X-100). (B) Circular dichroism spectra of purified proteins. (C) Dynamic light scattering results showing the size and the percentage of MamC protein particles of (C1) detergent-MamC experiment types and (C2) detergent-D-MamC experiment types compared to MamC-control.

The synthesized magnetic powders were dehydrated with ethanol and embedded in Embed 812 resin. Ultrathin sections $(50-70 \mathrm{~nm})$ were prepared using a Reichert Ultracut $S$ microtome (Leica Microsystems GmbH, Wetzlar, Germany) after which the sections were deposited onto copper electron microscopy grids. The morphology and particle size of synthesized nanocrystals were analyzed by transmission electron microscopy (TEM) (Philips Model CM20) equipped with an energy dispersive X-ray spectrometer (EDAX) and by high resolution TEM (HRTEM, FEI TITAN G2, The Netherlands). The size of the crystals was measured from TEM images using Image 1.47 software, and size distribution curves and statistical analyses were determined from these measurements using Origin pro 9. To ensure reproducibility of results, particle sizes were measured on multiple micrographs with an excess of 1000 nanoparticles measured for each experiment. To determine the crystallinity of magnetite, selected area electron diffraction (SAED) patterns were collected by using a $10 \mu \mathrm{m}$ aperture. D-spacings were measured from HRTEM images and crystallographic direction inferred by using magnetite data in RRUFF Project Web site (http://rruff.info/ams/amcsd.php). The visualization of the atomic planes (111), (311), (110), and (100) and the calculations of distance between iron atoms were performed using CrystalMaker Software.

\section{RESULTS}

Protein Purification and Aggregation. SDS-PAGE electrophoresis gels of the protein collected after dialysis show an intense, predominant band at $17.4 \mathrm{kDa}$, corresponding to the size of the recombinant MamC (Figure 1A). These results confirm that pure MamC (purity higher than 95\%) was obtained in all cases regardless of the presence of the detergents. This purity is similar to that obtained by Valverde-Tercedor et al. ${ }^{20}$
Circular dichroism (CD) spectra of each sample type show that MamC refolds in all cases, regardless of the presence of the detergents. This is indicated by the presence of a minimum at $222 \mathrm{~nm}$ (Figure 1B) characteristic of an $\alpha$-helix conformation, which is consistent with MamC theoretical structure presented by Nudelman and Zarivach. ${ }^{22}$ Dynamic light scattering (DLS) data of MamC-control shows that around $80 \%$ of the particles have a size of $7 \pm 1 \mathrm{~nm}$, although bigger protein particles $(21 \pm$ $4 \mathrm{~nm}$ and $55 \pm 1 \mathrm{~nm}$ ) are also detected at much lower percentages (Figure 1C). Smaller protein particles $(3-5 \mathrm{~nm}$ ) were obtained in the presence of detergents. In fact, $~ 90 \%$ of the particles fall within this size range in the presence of triton $\mathrm{X}-100$, irrespective of when this detergent is introduced in the purification protocol (Figure $1 \mathrm{C} 1$ and $\mathrm{C} 2$ ). The case of LDAO is similar, although a slightly higher number of smaller protein particles are obtained when this detergent is added to the cell extract and then after, rather than when added only during the dialysis (Figure $1 \mathrm{C} 1$ and $\mathrm{C} 2$ ). DDM only produces particles within the range $3-5 \mathrm{~nm}$ when it is added to the cell extract. However, in this case, it also increases the number of aggregates of $15-25 \mathrm{~nm}$ compared to the other detergents (Figure 1C1). When used during the dialysis (Figure 1C2), it yields similar protein particles to those obtained in the MamC-control experiment (no detergent added).

Characterization of Solids. X-ray diffraction (XRD) data (Figure S1) show that the solid phase obtained from the biomineralization experiments was mainly magnetite $(>85 \%)$ regardless of the presence of detergents. Goethite was also sometimes detected as a minor phase (up to $15 \%$ ).

Transmission electron microscopy (TEM) analyses of the solids show noticeable differences in the size of magnetite 

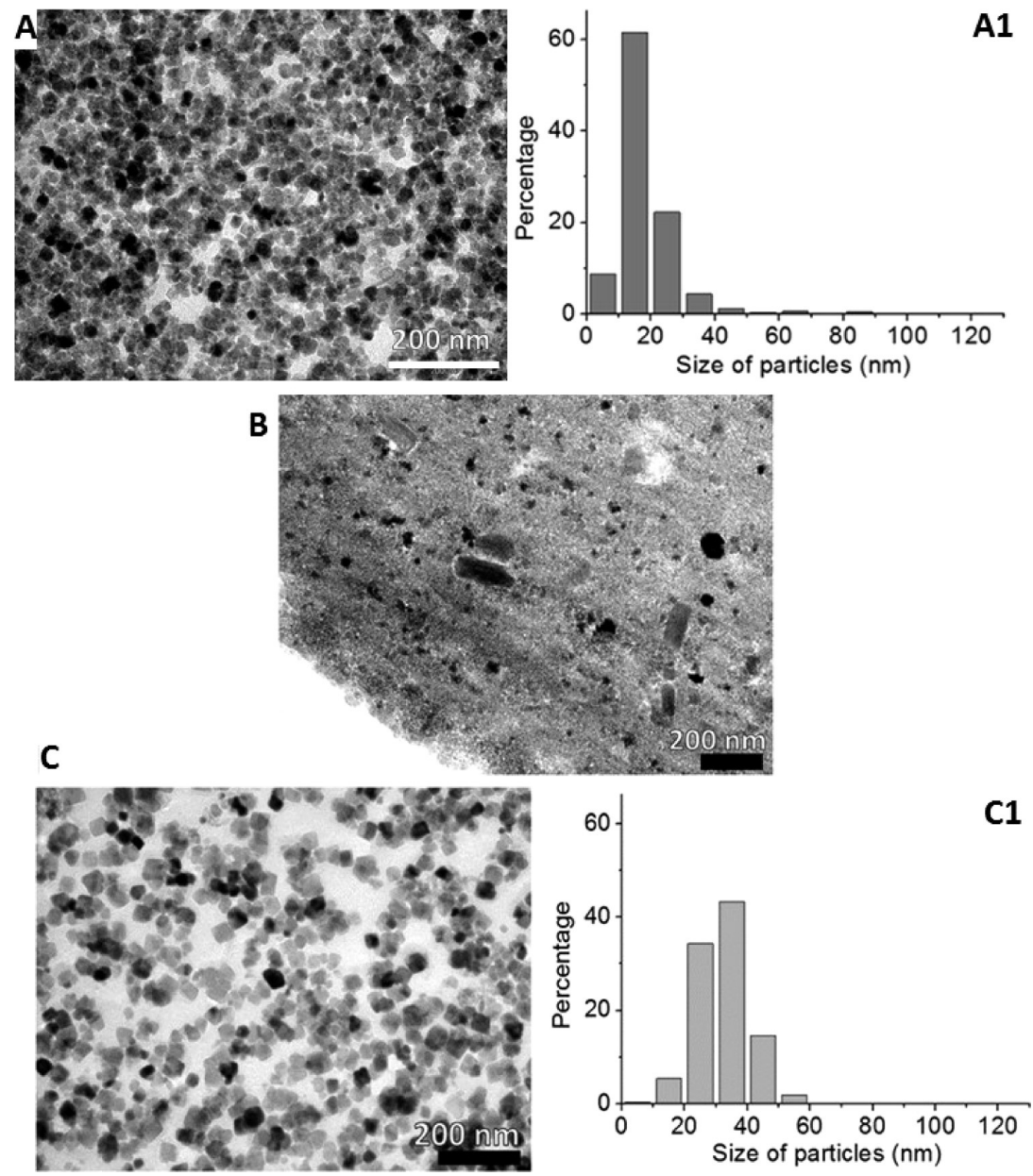

Figure 2. TEM images of magnetites nanoparticles obtained in the (A) wt-control and the corresponding size distribution (A1); (B) b-control; and (C) MamC-control experiments and size distribution (C1).

nanoparticles for the different biomineralization experiments. Whereas the wt-control shows magnetite nanoparticles of $19 \pm$ $11 \mathrm{~nm}$ (Figure 2A and Al), all b-control and bdet-controls show fine-grained $(<5 \mathrm{~nm})$ poorly crystalline nanoparticles (Figures 2B, 3A, 4A, and 5A).

Detergent-MamC experiments show very different results depending on the detergent used and when the detergent was introduced in the experiment. In the context of the timing at when the detergent was added, TEM analyses of the LDAOMamC and DDM-MamC solids show small magnetite nanoparticles $(<10 \mathrm{~nm})$ (Figures $3 \mathrm{~B}$ and $4 \mathrm{~B}$, respectively), significantly smaller than the particles obtained when no detergent was used at all [MamC-control particles, average size of $33 \pm 11 \mathrm{~nm}$, being over $50 \%$ of the crystals larger than 30 $\mathrm{nm}$ (Figure 2C and $\mathrm{C} 1$ )]. On the contrary, when LDAO and DDM were introduced during protein dialysis, the particle sizes were, respectively, of $51 \pm 15 \mathrm{~nm}$ (Figure 3C,C1) and $36 \pm 12$ $\mathrm{nm}$ (Figure 4C,C1). Magnetites produced in the presence of Triton, irrespective of when this detergent was added, show an average size of $22 \pm 8 \mathrm{~nm}$ (Triton-MamC) and $25 \pm 8 \mathrm{~nm}$ (Triton-D-MamC) (Figure 5B, C, B1, and C1). The size of these particles is significantly larger than that of the particles produced in the wt-control experiment but significantly smaller than that of the particles from MamC-control experiment (Figure 6).

Also, the morphology of the crystals seems to be affected by MamC (Figure 7). 2D images of the crystals from the inorganic wt-control experiments show squares, some hexagon and rhombic shapes bounded by (111) crystal faces. In some cases, some of the corners of these square shapes were not welldefined, and were rounded. These rounded corners can correspond to incipient (110) crystal faces. In MamC-bearing experiments, mainly rectangles, rhomboid, and hexagons shapes were found bounded by (111) crystal faces. Also, rounded corners were much more evident, showing up in many crystals, that may correspond to incipient (110) and (311) crystal faces. More interestingly, crystals appeared elongated along one [111] direction. The latter feature was not observed in crystals from the protein-free experiments.

\section{DISCUSSION}

bDDM-control, bLDAO-control, and bTriton-control experiments show a clear influence of the Tris buffer on magnetite precipitation. Such an effect has been pointed out before by Kuwahara et al., ${ }^{28}$ who demonstrated that Tris buffer (4 mass $\%)$ in an $\mathrm{Fe}^{3+} / \mathrm{Fe}^{2+}$ solution prevents magnetite nucleation, giving rise to akaganaeite formation instead. This is caused by the complexation of iron cations with the amino groups of Tris. In our experiments, Tris concentration (0.09 mass \%) was not enough to inhibit magnetite nucleation, but the size of the crystals was drastically reduced [compared to wt-control experiments (Tris-free)], probably due to the complexation of iron cations, which prevented further growth of the previously formed nuclei. 

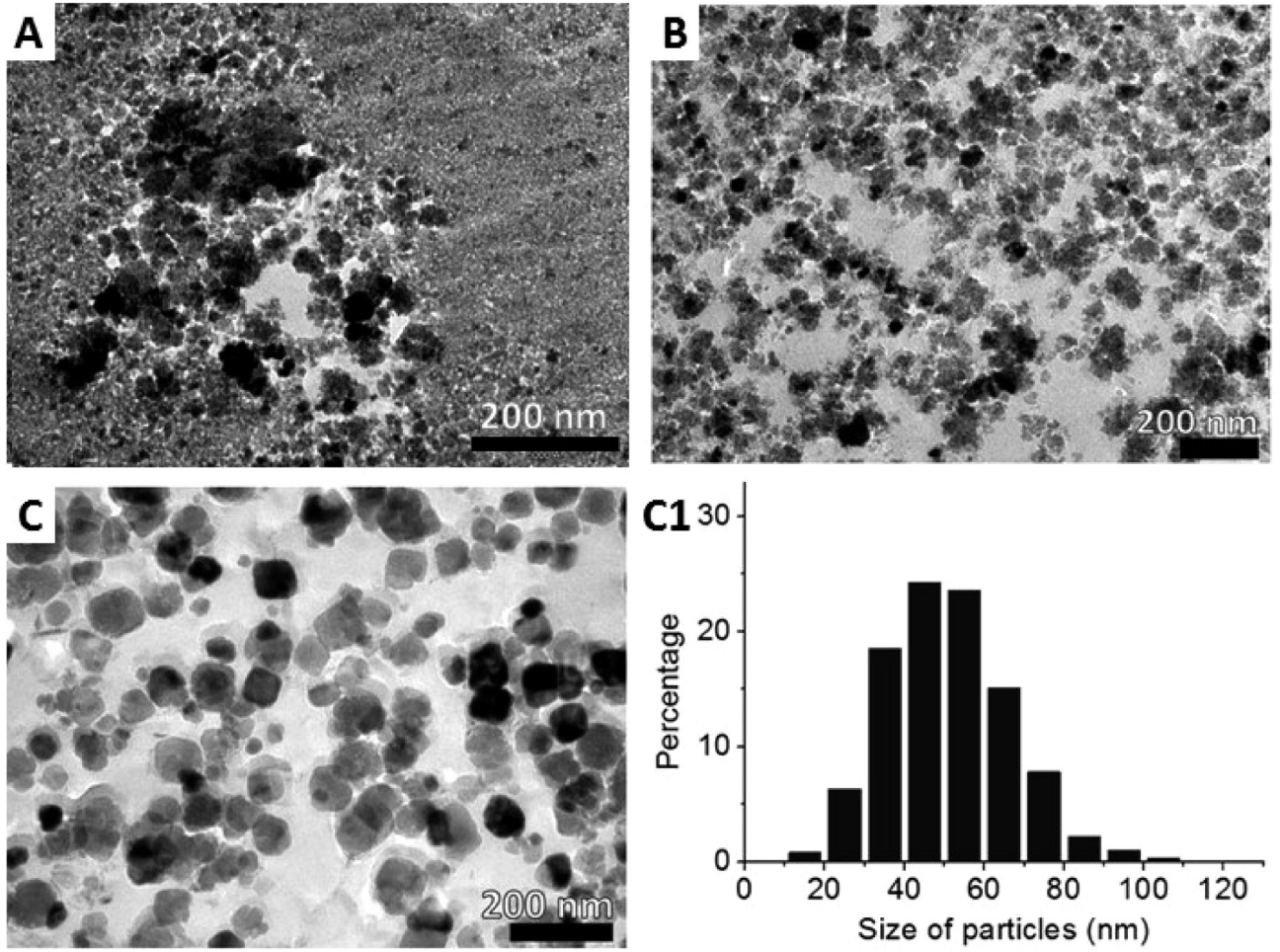

Figure 3. TEM images of magnetite nanoparticles obtained in (A) bLDAO-control; (B) LDAO-MamC; and (C) LDAO-D-MamC. Size distribution of LDAO-D-MamC particles (C1).
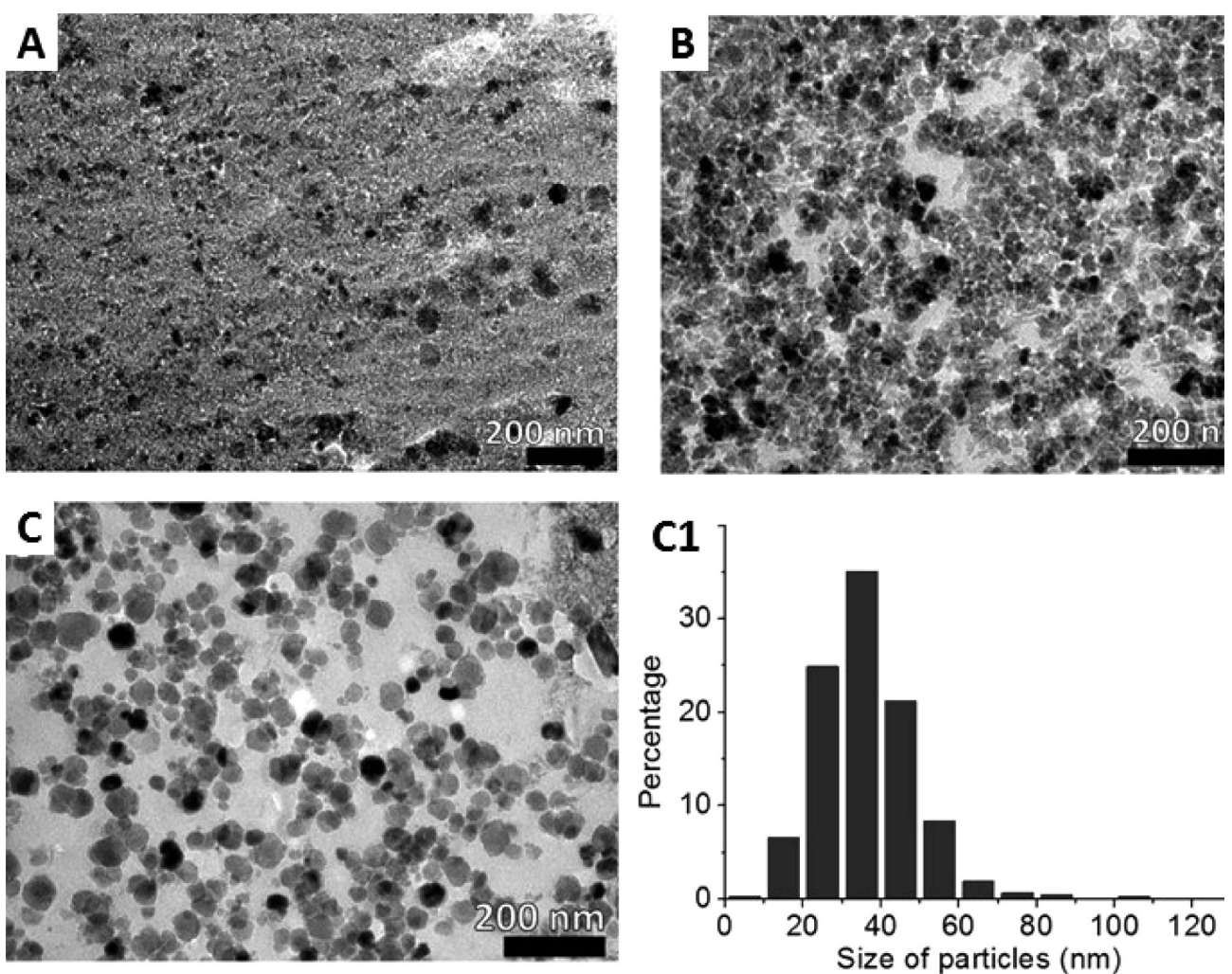

Figure 4. TEM images of magnetites nanoparticles obtained in (A) bDDM-control; (B) DDM-MamC; and (C) DDM-D-MamC experiments. Size distribution of DDM-D-MamC particles (C1).

Although in all cases MamC shows a similar $\alpha$ helix conformation consistent with previous theoretical models that represent it as an integral membrane protein with two transmembrane helices, ${ }^{22}$ the tertiary structure could vary due to the interaction of such a protein with the detergents. This interaction may result in the formation of protein aggregates (Figure 1C), and/or in different exposition of the acidic residues due to different protein conformation. Therefore, the 

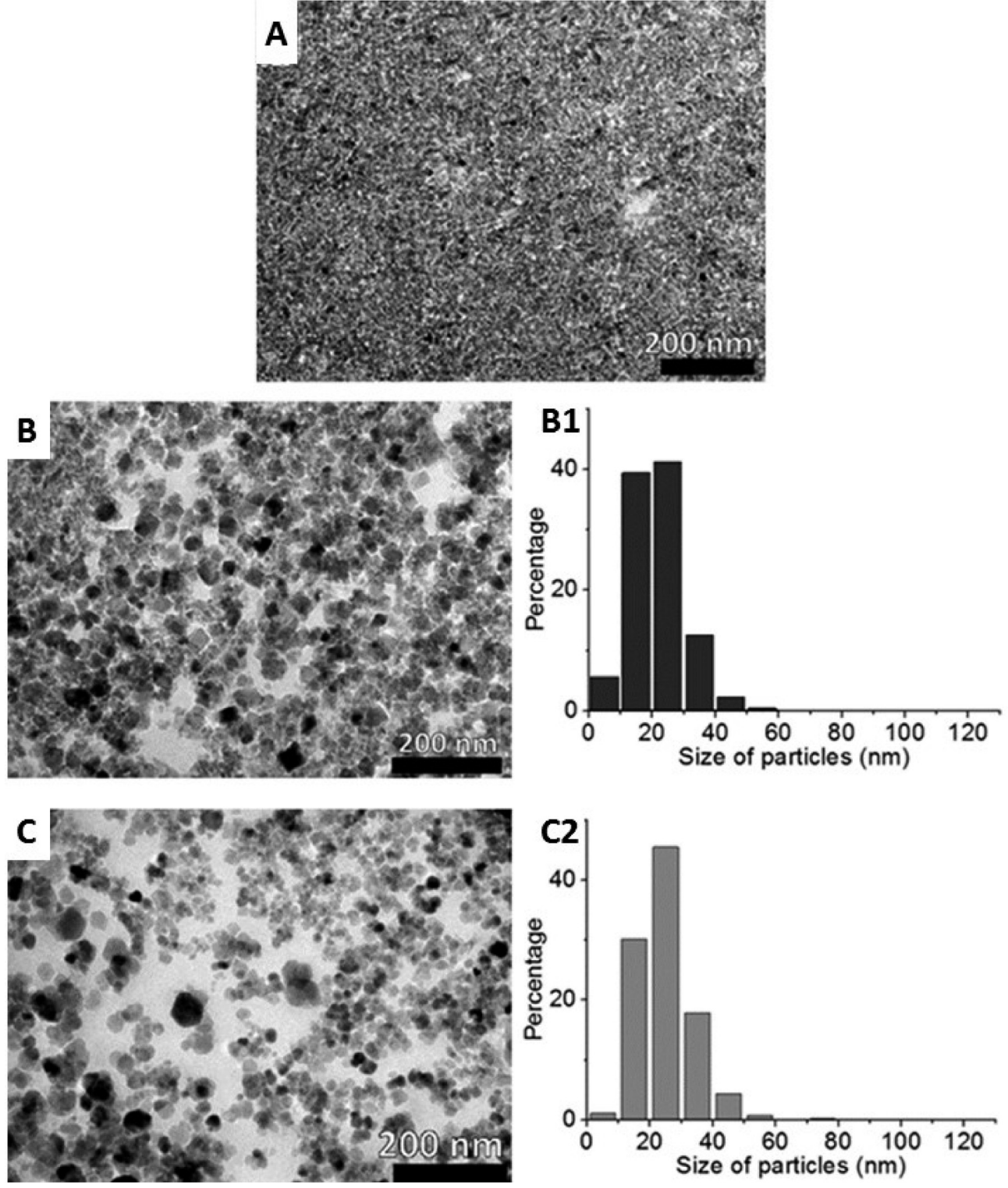

Figure 5. TEM images of magnetites nanoparticles obtained in the (A) bTriton-control; (B) Triton-MamC; (C) Triton-D-MamC. Size distribution of Triton-MamC (B1) and Triton-D-MamC particles (C1).

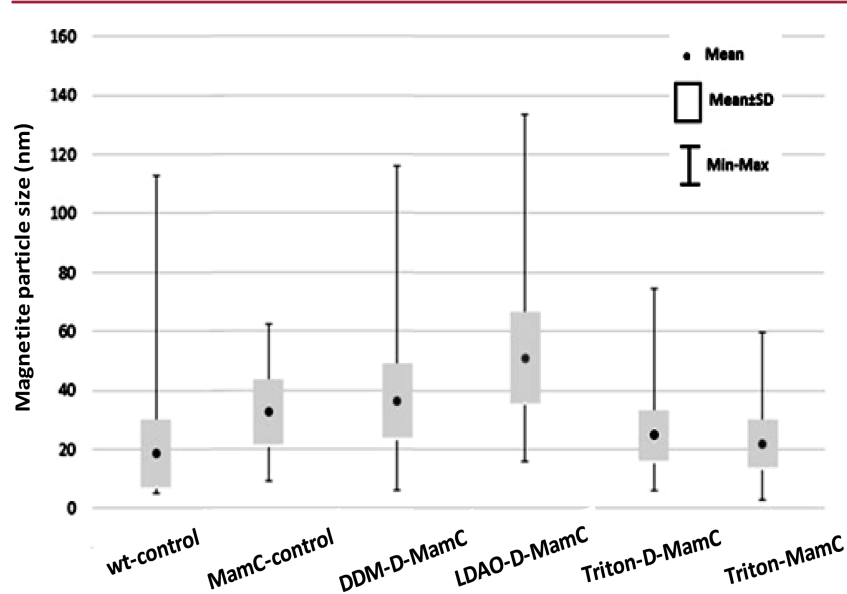

Figure 6. Histogram analyses and size distribution box plot. Statistical significance of different samples with respect control experiments was tested using the ANOVA test $\left(P<1.6 \times 10^{-12}\right)$. protein may (or may not) display a folding that permits, not only the creation of local high supersaturation areas, ${ }^{20}$ but a template effect for magnetite crystallization. ${ }^{24}$ DLS analyses of the protein particles in the present paper show different outputs depending on the use of detergents, the type of the detergent, and when it was introduced. Protein particles were $3-5 \mathrm{~nm}, 7$ $\mathrm{nm}, 15-25 \mathrm{~nm}$, and larger sizes. According to the model proposed by Wilkins and co-workers, ${ }^{29}$ and assuming a globular shape for monomeric MamC (133 residue), the hydrodynamic radius ranges from $2 \mathrm{~nm}$ (compact conformation) to $3.6 \mathrm{~nm}$ (extended conformation). Therefore, and following this assumption, particles with radii of 3-5, 7, and $15-25 \mathrm{~nm}$ will here be referred to as monomers, dimers, and trimers, respectively. DLS results show that no monomers were obtained when MamC was purified in the absence of detergents (MamC-control, Figure 1C), but rather, the unfolded eluted protein (U) refolded during dialysis mainly as dimers (FD) and, in a much lower percentage, as trimers (FT). This is consistent with the fact that MamC is a highly hydrophobic 

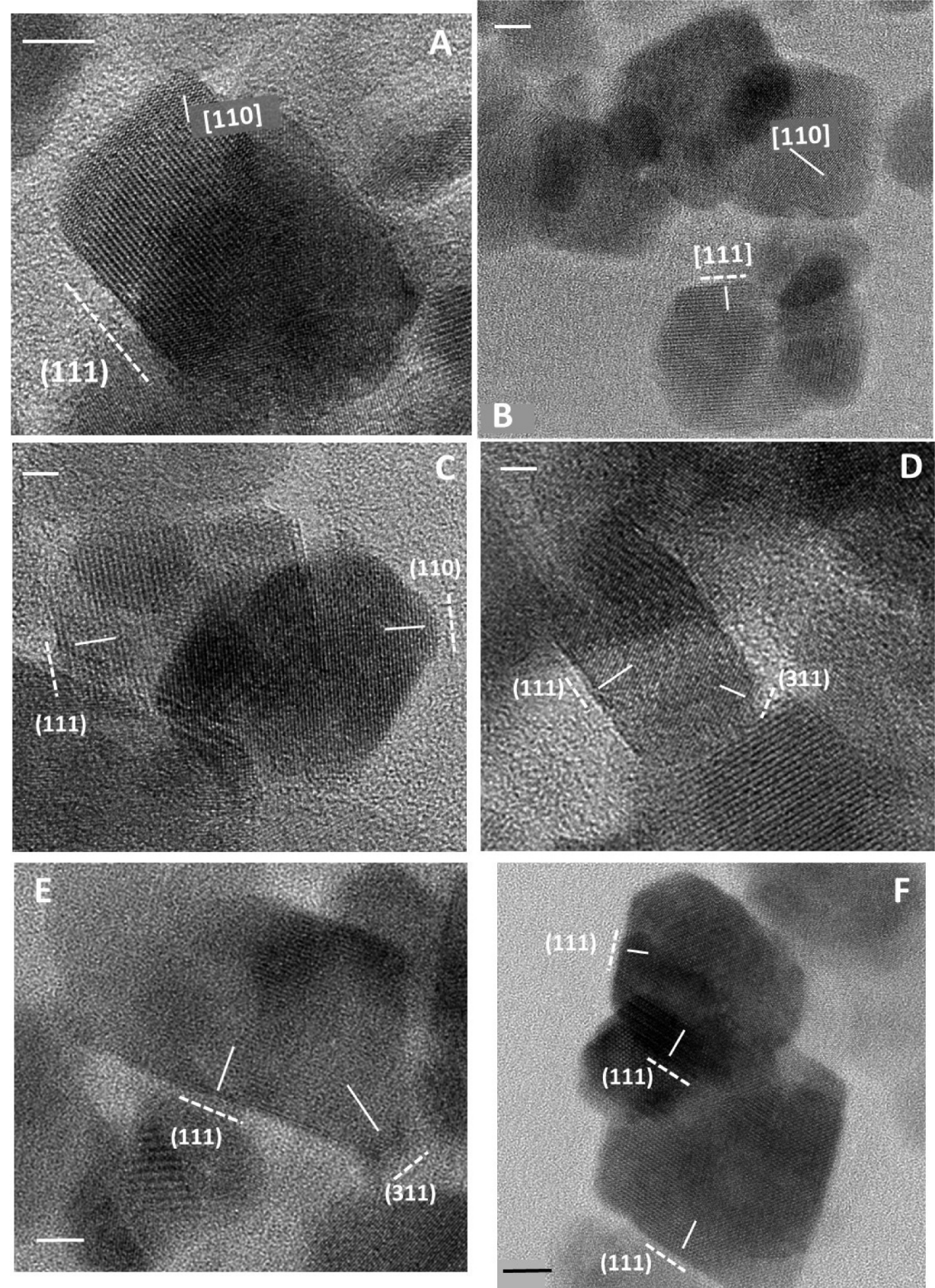

Figure 7. HRTEM images of inorganic magnetite (A and B) and magnetite from MamC-control experiments (C, D, E, and F). Solid lines represent measured atomic planes showing a crystallographic direction, while dotted lines represent expressed crystal faces. Scale bars $=5 \mathrm{~nm}$.

integral membrane protein $^{22}$ and, in solution, it requires shielding of the hydrophobic surface by oligomerization. In this scenario, the two highly hydrophobic transmembrane helices probably interact with other protein molecules forming the folded dimers and trimers observed (Table 1).

In detergent-MamC experiments and thanks to their amphiphilic character, ${ }^{30}$ DDM, LDAO, and Triton-X100 may interact with the unfolded protein preventing its aggregation. Such an interaction may occur by the attachment of the detergent monomers to the hydrophobic domains on the protein and/or by the insertion of the protein in the detergent micelles. $^{31}$ Therefore, the unfolded MamC purified in the presence of detergent, refolded mainly as monomers (FM) and, to a much lower extent, as trimers (FT) irrespective of the detergent type (Figure 1C1, Table 1). However, the effect on the size of the crystals due to the presence of these folded monomers during the in vitro magnetite precipitation is different. In fact, magnetite particles from LDAO-MamC and DDM-MamC experiments displayed crystal sizes comparable to those of the particles formed in bdet-control experiments (Figure 6), which indicates that only the buffer, and not the folded monomers, were controlling the precipitation of magnetite. Therefore, the folded monomers were not active, understanding by that they do not display a functional folding for magnetite precipitation because either they have an altered structure which prevents the monomer from exposing the domains rich in acidic amino acids or their folding does not allow the monomer to exhibit an extended surface for magnetite precipitation. The large micelles produced by DDM (in agreement with previous findings ${ }^{32}$ ) may include 
Table 1. Models of Interaction between the Detergent and the Protein during the Purification Process ${ }^{a}$

\begin{tabular}{|c|c|c|c|}
\hline \multirow{2}{*}{$\begin{array}{l}\text { experiment } \\
\text { type }\end{array}$} & \multicolumn{3}{|c|}{ state of the protein } \\
\hline & at the elution & dialysis & after dialysis \\
\hline $\begin{array}{l}\text { MamC- } \\
\text { control }\end{array}$ & $\mathrm{U}$ & $\mathrm{PF}-\mathrm{PF}-\ldots .$. & $\mathrm{FD}+\mathrm{FT}$ \\
\hline DDM-MamC & $\mathrm{U}(\mathrm{DDM})$ & $\mathrm{PF}(\mathrm{DDM})$ & $\mathrm{FM}^{*}(\mathrm{DDM})$ \\
\hline $\begin{array}{l}\text { LDAO- } \\
\text { MamC }\end{array}$ & $\mathrm{U}(\mathrm{LDAO})^{+}$ & $\mathrm{PF}(\mathrm{LDAO})^{+}$ & $\mathrm{FM}^{*}(\mathrm{LDAO})$ \\
\hline Triton-MamC & $\mathrm{U}$ (Triton) & $\mathrm{PF}$ (Triton) & FM(Triton) \\
\hline $\begin{array}{l}\text { DDM-D- } \\
\text { MamC }\end{array}$ & $\mathrm{U}$ & $\mathrm{PF}+\mathrm{DDM}$ & $\begin{array}{c}\mathrm{FD}(\mathrm{DDM})+ \\
\mathrm{FT}(\mathrm{DDM})\end{array}$ \\
\hline $\begin{array}{l}\text { LDAO-D- } \\
\text { MamC }\end{array}$ & $\mathrm{U}$ & $\begin{array}{l}\mathrm{U}(\mathrm{LDAO}) \rightarrow \\
\mathrm{PF}(\mathrm{LDAO})\end{array}$ & $\mathrm{FM}(\mathrm{LDAO})$ \\
\hline $\begin{array}{c}\text { Triton-D- } \\
\text { MamC }\end{array}$ & $\mathrm{U}$ & $\begin{array}{l}\mathrm{U}(\text { Triton) } \rightarrow \\
\quad \mathrm{PF}(\text { Triton) }\end{array}$ & FM(Triton) \\
\hline \multicolumn{4}{|c|}{$\begin{array}{l}{ }^{a} \mathrm{FM}=\text { folded monomer, } \mathrm{FD}=\text { folded dimer, } \mathrm{FT}=\text { folded trimer, } \mathrm{PF}= \\
\text { partially folded, } \mathrm{U}=\text { unfolded, } *=\text { altered state with native-like } \\
\text { secondary structure). Note: } \text { det }^{+} \text {indicates the charge of the detergent } \\
\text { at the specific } \mathrm{pH} \text { of the experiment. }\end{array}$} \\
\hline
\end{tabular}

the unfolded MamC preventing its functional folding. A similar mechanism was observed by Yang et al. ${ }^{33}$ while purifying NBD1 (nucleotide-binding domain 1, $130.4 \mathrm{kDa}$ ) in the presence of DDM. Also, an electrostatic interaction between LDAO and the negatively charged protein domains may occur, since LDAO is an ionic detergent positively charged at the elution $\mathrm{pH}(\mathrm{pH}=4)$. This interaction may prevent a correct folding of the protein resulting in the inactivation of MamC, as those negatively charged protein domains (those precisely that are essential for biomineralization) are sequestered.

As previously mentioned, MamC controls magnetite precipitation by (a) creating areas highly supersaturated with respect to magnetite induced by the accumulation of Fe cations in those areas (MamC loop and C-terminal) highly dense in acidic amino acids ${ }^{20}$ and (b) serving as a template model for magnetite nucleation, based on the fact that the distance between Glu66 and Asp70 in the MamC loop ( 8 $\AA$ ) matches that of Fe cations in (111), (100), and (110) atomic planes of magnetite. ${ }^{24}$ Such a hypothesis is further confirmed in the present study. Magnetites produced in the presence of MamC show specific crystal faces in their final morphology [(111), (311), (100), and (110)], some of which are not displayed in magnetite produced in protein free experiments. Precisely, the distance between $\mathrm{Fe}$ cations in tetrahedral and octahedral positions is 2.968 and $3.635 \AA$, respectively, in (111) faces (Figure S2), while in (311), (100), and (110) crystal faces Fe cations show a distance of $2.968 \AA$ (Figure S2). Multiples of these numbers precisely approximate the distance between those Glu66 and Asp70 carboxylic groups in MamC loop, allowing a potential template effect for magnetite nucleation and growth. In particular, the protein, as long as it is functionally folded, would not only concentrate Fe cations in their acidic residues, but also bind preferentially to the faces mentioned above, preventing their growth and allowing them to be expressed in the final morphology of the crystal, as shown in Figure 7. The latter mechanism could explain the observed elongation of crystal in one [111] direction.

Protein particles formed in Triton-MamC and Triton-Dexperiments are mainly monomers. Since the size of the magnetite nanoparticles obtained from both experiments is significantly larger than that of crystals from all inorganic controls, it can be concluded that these monomers are active.
At $1.3 \mathrm{CMC}$ there is an equilibrium between the detergent monomers and micelles, ${ }^{32}$ and since the size of the Triton $\mathrm{X}$ 100 micelles (checked by DLS) is $\sim 83 \mathrm{kDa}$ (exceeding the dialysis membrane cutoff of $12 \mathrm{kDa}$ ), only detergent monomers are able to interact with the unfolded MamC in Triton-DMamC, while both detergent monomers and micelles are able to interact with it in Triton-MamC experiments. Nevertheless, both monomers and micelles of Triton interact with unfolded MamC allowing the folding of MamC in active monomers. These results are in agreement with those of Le Maire et al., ${ }^{31}$ who demonstrated that Triton X-100 not only maintains the tertiary structure of membrane proteins, but also permits a correct folding of these proteins, allowing them to be functional. The smaller crystal sizes obtained in these Tritonbearing experiments compared to those of the particles from the MamC-control experiments may be due to an increase of nucleation sites for magnetite as the population of active monomers percentage increases in the former experiments, thus producing an intense nucleation of more crystals with smaller sizes. In fact, Valverde-Tercedor et al. ${ }^{20}$ demonstrated that an increase on the concentration of MamC in solution above a certain value (optimum value $=10 \mu \mathrm{g} / \mathrm{mL}$ ) results in a drastic decrease of the size of the crystals caused by an intense nucleation. Therefore, even though the concentration of MamC was equal in all experiments, the larger the number of active monomers, the larger the number of nucleation sites, and therefore, the strongest the nucleation event in a situation comparable to that created by an increase on the protein concentration in the aqueous solution.

Still, different outputs were obtained in the case of DDM and LDAO when both detergents were added during the protein refolding process (detergent-D-MamC experiments). Dissimilar protein particles were obtained depending on the detergent used. While in DDM-D-MamC experiments the unfolded MamC mainly refolded as dimers and trimers, in LDAO-DMamC experiments MamC refolded mainly as monomers and trimers (Figure 1C, Table 1). The size of the DDM and LDAO micelles (analyzed by DLS) was $\sim 80 \mathrm{kDa}$ and $\sim 20 \mathrm{kDa}$, respectively. As in the case of Triton X-100, the cutoff of the dialysis membrane does not permit the diffusion of the large detergent micelles throughout, and thus, only detergent monomers are able to interact with the unfolded MamC. Based on that, the results obtained, regarding MamC oligomerization state and their role on magnetite precipitation, have to be interpreted in terms of the denaturing mildness of the detergent. In this context, it has been pointed out that DDM is a gentle detergent where LDAO is harsher. ${ }^{32}$ DDM was not able to prevent the formation of dimers (Figure 1C2), because DDM detergent monomers were too soft, because the concentration of them within the dialysis tubing was too low (equilibrium constants between monomers and micelles for DDM are not available in the literature at the present), and/or because there was a kinetic competition between monomer diffusion through the membrane pores and the rate at which the unfolded MamC was refolding. Although the specific cause cannot be argued at the present, MamC refolded as if there was no detergent (mainly as dimers as in MamC-control experiments). These dimers were however active, since magnetite nanoparticles produced in DDM-D-MamC experiment were significantly larger than those obtained in the protein-free experiments and similar in size compared to those produced in MamC-control experiments. 
In contrast, LDAO monomers were able to prevent oligomerization of the unfolded MamC (Figure 1C2), resulting in a high percentage of MamC monomers. Moreover, the size of magnetite crystals produced in LDAO-D-MamC experiments are the largest (Figure 6), thus showing that these MamC folded monomers are active, although their concentration may not be as high as in the Triton X-100 bearing experiments. This hypothesis is well supported by previous findings ${ }^{32}$ that show that LDAO is a relatively harsh detergent, and only about $20 \%$ of the membrane proteins tested were resistant to its denaturing effects. ${ }^{34}$

It was previously suggested by Amemiya et al. ${ }^{16}$ and Rawlings et al. ${ }^{35}$ (in their studies about Mms6 and MmsF, respectively) that aggregates are the active form of these proteins, but no biomineralization experiment was performed in the presence of monomers to determine whether or not there was any activity in the monomeric form. However, our experiments suggest that a straightforward correlation between the oligomeric state of the protein and the size of magnetite crystals is not possible, since other factors, such as the population of the active protein particles that are present at a certain oligomeric state, need to be taken into account.

\section{CONCLUSIONS}

Results presented here show that the structure of MamC is important in relation to the role of such a protein in the magnetite precipitation process. This is not only because MamC creates areas that locally enhance the supersaturation of the system with respect to magnetite in protein domain rich in acidic amino acids, but also because such a protein may create a template effect due to the approximate distance between Glu66-Asp70 and the Fe cations in (111), (311), and (110) planes, which become expressed in the final morphology of the crystals and results in the elongation of those crystals in one [111] direction. Therefore, when such a protein is expressed as recombinant protein and purified under denaturing conditions, much care is needed in order to obtain nonaggregated forms that have a functional structure. Our experiments show that the introduction of detergents only during the dialysis process, rather than throughout the purification process, prevents protein aggregation and allows a correct, functional folding of MamC. Among the detergents tested in this work, the use of LDAO seems to yield the better results in terms of the production of larger magnetite particles. Moreover, the population of the active protein particles that are present in a certain oligomeric state needs to be considered rather than only the oligomeric state of such a protein in order to interpret the effect of these magnetosome recombinant proteins on magnetite precipitation.

\section{ASSOCIATED CONTENT}

\section{S Supporting Information}

The Supporting Information is available free of charge on the ACS Publications website at DOI: 10.1021/acs.cgd.6b01643.

Figure S1: Summary of the different experiment types that were run in the manuscript. Figure S2: XRD measurements of the magnetites formed in each experiment type, showing that the minerals obtained in all experiments are mainly magnetite and, in some cases, goethite also formed as a minor phase. Figure S3: Models for the magnetite faces detected by HRTEM in which the $d$-spacing between the Fe planes for each crystal face is calculated. (PDF)

\section{AUTHOR INFORMATION}

\section{Corresponding Author}

*E-mail: cjl@ugr.es.

ORCID $\odot$

Concepcion Jimenez-Lopez: 0000-0002-5645-2079

\section{Author Contributions}

The manuscript was written through contributions of all authors. All authors have given approval to the final version of the manuscript. C.J.L., M.A.F.V., C.V.T., and R.Z. planned the research and designed the experiments. R.L.M. performed the experiments, initiated by C.V.T., and analyzed the samples. He also wrote a first draft of the manuscript. A.I.A.F. and S.C.A. designed the $C D$ and DLS experiments and discussed the results obtained. A.R.N. designed the HRTEM experiments and discussed those results. C.J.L. rewrote the subsequent versions of the paper to the final form and took care of the revised versions, with the input and discussion from all authors.

\section{Funding}

Grants CGL2013-46612 and CGL2016-76723 from the Ministerio de Economía y Competitividad from SPAIN and Fondo Europeo de Desarrollo Regional (FEDER).

\section{Notes}

The authors declare no competing financial interest.

\section{ACKNOWLEDGMENTS}

The authors wish to thank support from the projects CGL2013-46612 and CGL2016-76723 from the Ministerio de Economía y Competitividad from SPAIN and Fondo Europeo de Desarrollo Regional (FEDER). Thanks go to CIC personnel of the University of Granada for XRD, TEM, and HRTEM analyses. We also want to thank two anonymous reviewers for their comments that greatly improved the manuscript.

\section{REFERENCES}

(1) Blakemore, R. P. Science 1975, 190, 377-379.

(2) Bazylinski, D. A.; Frankel, R. B. Nat. Rev. Microbiol. 2004, 2 (3), 217-30.

(3) Jogler, C.; Kube, M.; Schübbe, S.; Ullrich, S.; Teeling, H.; Bazylinski, D. Environ. Microbiol. 2009, 11, 1267-1277.

(4) Thomas-Keprta, K. L.; Bazylinski, D.; Kirschvink, J. L.; Clemett, S. J.; McKay, D. S.; Wentworth, S. J.; Vali, H.; Gibson, E. K.; Romanek, C. S. Geochim. Cosmochim. Acta 2000, 64, 4049-4081.

(5) Alphandéry, E.; Ngo, A. T.; Lefêvre, C.; Lisiecki, I.; Wu, L. F.; Pileni, M. P. J. Phys. Chem. C 2008, 112, 12304-12309.

(6) Sun, J. B.; Tang, T.; Duan, J.; Xu, P. X.; Wang, Z.; Zhang, Y.; Wu, L.; Li, Y. Nanotoxicology 2010, 4 (3), 271-283.

(7) Matsunaga, T.; Suzuki, T.; Tanaka, M.; Arakaki, A. Trends Biotechnol. 2007, 25, 182-188.

(8) Lisy, M. R.; Hartung, A.; Lang, C.; Schüler, D.; Richter, W.; Reichenbach, J. R.; Kaiser, W. A.; Hilger, I. Invest. Radiol. 2007, 42 (4), 235-241.

(9) Ota, H.; Lim, T. K.; Tanaka, T.; Yoshino, T.; Harada, M.; Matsunaga, T. J. Biotechnol. 2006, 125, 361-368.

(10) Maruyama, K.; Takeyama, H.; Nemoto, E.; Tanaka, T.; Yoda, K.; Matsunaga, T. Biotechnol. Bioeng. 2004, 87, 687-694.

(11) Maruyama, K.; Takeyama, H.; Mori, T.; Ohshima, K.; Ogura, S.; Mochizuki, T.; Matsunaga, T. Biosens. Bioelectron. 2007, 22, 22822288.

(12) Alphandéry, E.; Faure, S.; Seksek, O.; Guyot, F.; Chebbi, I. ACS Nano 2011, 5, 6279-6296. 
(13) Sun, J. B.; Duan, J. H.; Dai, S. L.; Ren, J.; Guo, L.; Jiang, W.; Li, Y. Biotechnol. Bioeng. 2008, 101 (6), 1313-1320.

(14) Kolinko, I.; Lohße, A.; Borg, S.; Raschdorf, O.; Jogler, C.; Tu, Q.; Pósfai, M.; Tompa, E.; Plitzko, J.; Brachmann, A.; Wanner, G.; Müller, R.; Zhang, Y.; Schüller, D. Nat. Nanotechnol. 2014, 9, 193197.

(15) Arakaki, A.; Webb, J.; Matsunaga, T. J. Biol. Chem. 2003, 278, $8745-8750$.

(16) Amemiya, Y.; Arakaki, A.; Staniland, S.; Matsunaga, T. Biomaterials 2007, 28, 5381-5389.

(17) Prozorov, T.; Mallapragada, S.; Narasimhan, B.; Wang, L.; Palo, P.; Nilsen- Hamilton, M.; Williams, T. J.; Bazylinski, D. A.; Prozorov, R. Adv. Funct. Mater. 2007, 17, 951-957.

(18) Rawlings, A. E.; Bramble, J. P.; Hounslow, A. M.; Williamson, M. P.; Monnington, A. E.; Cooke, D. J.; Staniland, S. S. Chem. - Eur. J. 2016, 22 (23), 7885-7894.

(19) Bird, S. M.; Rawlings, A. E.; Galloway, J. M.; Staniland, S. S. RSC Adv. 2016, 6, 7356-7363.

(20) Valverde-Tercedor, C.; Montalbán-López, M.; Perez-Gonzalez, T.; Sanchez-Quesada, M. S.; Prozorov, T.; Pineda-Molina, E.; Fernandez-Vivas, A.; Rodriguez-Navarro, A. B.; Trubitsyn, D.; Bazylinski, D. A.; Jimenez-Lopez, C. Appl. Microbiol. Biotechnol. 2015, 99, 5109-5121.

(21) Komeili, A. FEMS Microbiol. Rev. 2012, 36, 232-255.

(22) Nudelman, H.; Zarivach, R. Front. Microbiol. 2014, 5, 9.

(23) Peigneux, A.; Valverde-Tercedor, C.; Lopez-Moreno, R.; PerezGonzalez, T.; Fernandez-Vivas, M. A.; Jimenez-Lopez, C. J. Struct. Biol. 2016, 196, 75.

(24) Nudelman, H.; Valverde-Tercedor, C.; Kolusheva, S.; Perez Gonzalez, T.; Widdrat, M.; Grimberg, N.; Levi, H.; Nelkenbaum, O.; Davidov, G.; Faivre, D.; Jimenez-Lopez, C.; Zarivach, R. J. Struct. Biol. 2016, 194 (3), 244-252.

(25) Kashyap, S.; Woehl, T.; Valverde-Tercedor, C.; SanchezQuesada, M.; Jimenez-Lopez, C.; Prozorov, T. J. Nanomater. 2014, 2014, 320124.

(26) Perez-Gonzalez, T.; Rodriguez-Navarro, A.; Jimenez-Lopez, C. J. Supercond. Novel Magn. 2011, 24, 549-557.

(27) Martín-Ramos, J. D. Using XPowder, a software package for powder X-Ray diffraction analysis, 2004; D.L.GR-1001/04, Spain; pp $1-105$.

(28) Kuwahara, Y.; Miyazaki, T.; Shirosaki, Y.; Liu, G.; Kawashita, M. Ceram. Int. 2016, 42, 6000-6004.

(29) Wilkins, D. K.; Grimshaw, S. B.; Receveur, V.; Dobson, C. M.; Jones, J. A.; Smith, L. J. Biochemistry 1999, 38 (50), 16424-16431.

(30) Otzen, D. E. Biophys. J. 2002, 83, 2219-2230.

(31) Le Maire, M.; Champeil, P.; Moeller, J. V. Biochim. Biophys. Acta, Biomembr. 2000, 1508, 86-111.

(32) Privé, G. G. Methods 2007, 41, 388-397.

(33) Yang, Z.; Wang, C.; Zhou, Q.; An, J.; Hildebrandt, E.; Aleksandrov, L. A.; Kappes, J. C.; De Lucas, L. J.; Riordan, R. J.; Urbatsch, I. L.; Hunt, J. F.; Brouillette, C. G. Protein Sci. 2014, 23 (6), 769-789.

(34) Michel, H. in International Tables for Crystallgraphy Vol. F, Rossmann, M.; Arnold, E., Eds.; Kluwer Academic Publishers: Dordrecht, 2001; pp 94-100.

(35) Rawlings, A. E.; Bramble, J. P.; Walker, R.; Bain, J.; Galloway, J. M.; Staniland, S. S. Proc. Natl. Acad. Sci. U. S. A. 2014, 111 (45), 16094-10699. 